\title{
Responses of shelterbelt stand transpiration to drought and groundwater variations in an arid inland river basin of Northwest China
}

\author{
Qin Shen ${ }^{\mathrm{a}}$, Guangyao Gao ${ }^{\mathrm{a}, \mathrm{b}, *}$, Bojie Fu ${ }^{\mathrm{a}, \mathrm{b}}$, Yihe Lü ${ }^{\mathrm{a}, \mathrm{b}}$ \\ a State Key Laboratory of Urban and Regional Ecology, Research Center for Eco-Environmental Sciences, Chinese Academy of Sciences, Beijing 100085, China \\ ' Joint Center for Global Change Studies, Beijing 100875, China
}

\section{A R T I C L E I N F O}

\section{Article history:}

Received 25 March 2015

Received in revised form 7 October 2015

Accepted 19 October 2015

Available online 26 October 2015

This manuscript was handled by Corrado

Corradini, Editor-in-Chief, with the

assistance of Ming Ye, Associate Editor

\section{Keywords:}

Shelter-belt transpiration

Canopy conductance

Soil drought

Groundwater variation

Heihe River Basin

\begin{abstract}
S U M M A R Y
Plant water use characteristics and transpiration responses under dry conditions are considered essential for effective and sustainable ecosystem management in arid areas. This study was conducted to evaluate the response of shelterbelt stand transpiration to precipitation, soil drought and groundwater variations in an oasis-desert ecotone in the middle of the Heihe River Basin, China. Sap flow was measured in eight Gansu Poplar trees (Populus Gansuensis) with different diameter at breast height over three consecutive growing seasons (2012-2014). The groundwater evapotranspiration via plant use was estimated by the White method with diurnal water table fluctuations. The results showed that precipitation increased the stand transpiration but not statistically significant (paired $t$-test, $p>0.05$ ). The recharge of soil water by irrigation caused stand transpiration acceleration significantly ( $t$-test, $p<0.05)$. Stand transpiration and canopy conductance increased by $27 \%$ and $31 \%$, respectively, when soil water conditions changed from dry to wet. Canopy conductance decreased logarithmically with vapor pressure deficit, while there was no apparent relationship between canopy conductance and solar radiation. The sensitivity of canopy conductance to vapor pressure deficit decreased under dry soil conditions. Groundwater evapotranspiration $\left(0.6-7.1 \mathrm{~mm} \mathrm{day}^{-1}\right)$ was linearly correlated with stand transpiration $\left(1.1-6.5 \mathrm{~mm} \mathrm{day}^{-1}\right)\left(R^{2}=0.71\right)$, and these two variables had similar variability. During the drought period, approximately $80 \%$ of total stand transpiration came from groundwater evapotranspiration. This study highlighted the critical role of irrigation and groundwater for shelterbelt, and might provide the basis for the development of water requirement schemes for shelterbelt growth in arid inland river basins.
\end{abstract}

(c) 2015 Elsevier B.V. All rights reserved.

\section{Introduction}

Water scarcity has become an increasingly serious problem in arid areas, due to low precipitation and dry climate. Global warming has led to a higher evaporative demand, and the plant water use would experience a great change. The rate of plant water use under a given microclimate condition generally depends on available water for plant uptake, root distribution, and species sensitivity to soil and atmospheric drought (Oren et al., 1996). It is critical to understand the water use characteristic and physiological responses of arid plant species to drought and the underlying mechanisms for accurately predicting long-term ecosystem carbon, water, and energy fluxes (Naithani et al., 2012).

\footnotetext{
* Corresponding author at: State Key Laboratory of Urban and Regional Ecology, Research Center for Eco-Environmental Sciences, Chinese Academy of Sciences, Beijing 100085, China. Tel.: +86 1062841239 .

E-mail address: gygao@rcees.ac.cn (G. Gao).
}

The precipitation and soil water condition have an integrated influence on plant water use. Previous studies about the response of plant water use to precipitation mainly involved precipitation manipulation experiments for investigating the effect of precipitation changes on plant response (Limousin et al., 2009). Zhao and Liu (2010) used the "threshold-delay" model to acquire the threshold of the rainfall pulses on desert shrubs transpiration (Nitraria sphaerocarpa and Elaeagnus angustifolia). The response of plant water use to precipitation and soil water conditions is associated with stomatal control. Stomatal closure was identified as the main mechanism to regulate transpiration, avoiding irreversible damage to plant hydraulic system (Addington et al., 2004). Under drought stress conditions, stomatal conductance decreased with decreasing hydraulic conductance along the soil-to-leaf pathway due to high vapor pressure deficit (Motzer et al., 2005), xylem cavitation (Eberbach and Burrows, 2006), or soil dryness (O'Grady et al., 2008). The transpiration and canopy conductance in Eucalyptus globulus has been shown to be lower under rain-fed conditions compared to irrigation conditions, probably due to the decrease 
in soil-to-leaf hydraulic conductance and pre-dawn leaf water potential with the increasing soil water deficit (O'Grady et al., 2008). However, a study of two species (beech and spruce) in the Tharandt forest, Germany showed that soil water shortage led to a significant reduction in the transpiration rate of spruce, but not of beech (Schwärzel et al., 2009). Root distribution reduces the influence of soil water drought on plant transpiration, especially in deep-rooted species that have the ability to access and utilize deep soil water and groundwater overcoming soil drought without any significant changes in transpiration (Prieto et al., 2010).

Besides atmospheric and soil drought, groundwater variations have a significant effect on plant water use, especially for phreatophytes in arid inland river areas with shallow water table depth. To understand the interaction between deep soil water content and plant transpiration in shallow water table areas, it is necessary to monitor the water table fluctuations, water fluxes and ecophysiological characteristics within the groundwater-soil-plant-atmo sphere continuum (GSPAC) system in a dynamic way (Vincke and Thiry, 2008). Various methods have been used to collect data on water flux in the GSPAC system, including sap flow, stable isotope-based and meteorological methods (Williams et al., 2004), numerical models (Loheide et al., 2005), and diurnal water table fluctuation (WTF) method (Gribovszki et al., 2010).

The WTF method was first proposed by White (1932), and it has been recognized as a simple and effective method to obtain groundwater evapotranspiration for plant consumption in shallow groundwater area, because only the daily variation of water table depth and specific yield need to be measured. In cases wherein groundwater was the dominant source for plant water use, groundwater evapotranspiration estimated by the WTF method was well related to plant transpiration measured by sap flow or eddy covariance methods. Miller et al. (2010) used the WTF method and sap flow measurements of deciduous blue oak trees (Quercus douglasii) in a California oak savanna and showed that around $80 \%$ of total evapotranspiration derived from groundwater during the dry season. Therefore, a comprehensive investigation combining plant stand transpiration monitoring with the WTF method is essential to reliably quantify plant water use characteristics and transpiration responses to drought and groundwater variations in arid areas.

In the arid inland river basin, such as Heihe River Basin, China, groundwater serves as an important water source for phreatophytes, especially when soil water is depleted and becomes unavailable to plants. Gansu Poplar (Populus Gansuensis) trees were planted to act as a cropland shelterbelt in the oasis-desert ecotone in the middle of the Heihe River Basin. Information on water use of Gansu Poplar trees is extremely important not only for the proper management of the water resource, but also for the survival of the shelterbelt and the sustainability of the oasis. The effects of environmental factors on sap flow and water use of Gansu Poplar have been studied by Chang et al. (2006) and Shen et al. (2014). However, issues such as the response of stand transpiration and canopy conductance to drought and groundwater variations as well as the estimation of stand transpiration in Gansu Poplar shelterbelt from groundwater evapotranspiration, need further investigation.

In this study, diurnal sap flow of eight Gansu Poplar trees with different diameters at breast height, as well as soil water and water table variations in the shelterbelt stand were measured in the middle of the Heihe River Basin over three consecutive growing seasons (2012-2014). We utilized stand transpiration measurements and groundwater hydrographs to: (1) investigate the effects of precipitation, soil water, and groundwater conditions on stand transpiration and canopy conductance; (2) determine the quantitative relationships between stand transpiration or canopy conductance with meteorological factors under wet and dry conditions; and (3) study the daily groundwater evapotranspiration based on the White method to estimate the contribution of the groundwater to stand transpiration during the drought periods.

\section{Materials and methods}

\subsection{Site description}

The study area was located in a desert-oasis ecotone in the middle of Heihe River Basin, Linze County, Gansu province, China $\left(39^{\circ} 21^{\prime} \mathrm{N}, 100^{\circ} 07^{\prime} \mathrm{E}, 1374 \mathrm{~m}\right.$ above sea level). The area has a continental arid temperate climate. The average annual precipitation is $116.8 \mathrm{~mm}$ and the potential evaporation is $2390 \mathrm{~mm}_{\text {year }}{ }^{-1}$. The average annual temperature is $7.6{ }^{\circ} \mathrm{C}$ with the highest temperatures being at $39.1^{\circ} \mathrm{C}$ in July and lowest at $-27.3^{\circ} \mathrm{C}$ in January. The main soil types are sandy loam, sandy soil and greyishbrown desert soil. The site geology is characterized by a multilayer structure, consisting of gigantic rock debris and water-bearing rocks. The groundwater layer can be divided into two parts, an upper and a lower layer. The upper layer is a shallow unconfined aquifer, while the lower one is a multi-layered structure. The main plant types in this desert-oasis ecotone are poplar shelterbelt trees, shrub sand-fixation plants and other desert species, including $P$. Gansuensis, Populus bolleana, Calligonum mongolicum, Hedysarum scoparium, Tamarix chinensis, N. sphaerocarpa, Reaumuria soongorica, Bassia dasyphylla, Halogeton arachnoideus, Suaeda glauca, Agriophyllum squarrosum, and Eragrostis pilosa.

The experiment was conducted in a shelterbelt stand, consisting of Gansu Poplar trees, over three consecutive growing seasons (2012-2014). Gansu Poplar trees were planted in 1982. The topography was flat. The understory vegetation was sparse, and some Phragmites communis, Tribulus terrestris, Sonchus oleraceus, Astragalus adsurgens, Chenopodium album were found. The shelterbelt was irrigated using conventional flood irrigation on June 20 in 2012, May 19 in 2013 and June 11 in 2014 with an irrigation amount of about $250 \mathrm{~mm}$.

\subsection{Measurements of stand transpiration and environmental variables}

A plot ( $20 \mathrm{~m}$ length $\times 12 \mathrm{~m}$ width) with 34 individual trees was selected. Detailed information on soil properties of the study plot was provided in a previous study (Shen et al., 2014). Eight trees with different diameters at breast height $(\mathrm{DBH}, \mathrm{cm})$ were chosen as described by Shen et al. (2014). DBH of the eight sample trees ranged from 21 to $38 \mathrm{~cm}$, covering the full range of tree diameter classes in the plot. Sap flow was measured with constant heat flow gauges using the Granier type thermal dissipation sensor (TDP30, Rain Root Scientific Limited Company, Beijing, China). The detailed procedure to measure sap flow can be found in Shen et al. (2014).

Sap flow density $\left(S F_{d}, \mathrm{~g} \mathrm{~m}^{-2} \mathrm{~s}^{-1}\right)$ on sapwood area basis was calculated based on the temperature difference $\left(\Delta T,{ }^{\circ} \mathrm{C}\right)$ between the heated and unheated probes by an empirical calibration equation determined by Granier (1985):

$S F_{d}=118.99\left[\left(\Delta T_{\max }-\Delta T\right) / \Delta T\right]^{1.231}$

where $\Delta T_{\max }$ is the maximal temperature difference with zero sap flow assumed at night $\left({ }^{\circ} \mathrm{C}\right)$.

Sapwood area $\left(A_{s}, \mathrm{~cm}^{2}\right)$ was calculated based on the area between the bark and the heartwood. The distinction between sapwood and heartwood was identified by the difference in color. Twenty-six trees were randomly selected to measure DBH and $A_{s}$ from the nearby cut trunks. DBH ranged from 15 to $35 \mathrm{~cm}$, and the relationship between $A_{s}$ and DBH was significant $(p<0.05)$ $\left(A_{s}=25.91 \mathrm{DBH}-311.96, R^{2}=0.94\right)$. The above regression equation was used to estimate $A_{s}$ of all trees in the plot. The calculated total 
sapwood area in the plot was $1.56 \mathrm{~m}^{2}$. Furthermore, TDP sensors were inserted in the sapwood area of all sample trees.

Sap flux $\left(S F, \mathrm{~kg} \mathrm{day}^{-1}\right)$ was derived from the product of $S F_{d}$ by $A_{s}$ based on the assumption of a uniform radial $S F$ profile. Furthermore, the changes in DBH and $A_{s}$ over the three consecutive growing seasons were very low and could be ignored.

$S F=\frac{86.4 S F_{d} A_{s}}{10000}$

Stand transpiration $\left(E_{c}, \mathrm{~mm} \mathrm{day}^{-1}\right)$ was obtained by $S F$ and crown projected area $\left(A_{c}, \mathrm{~m}^{2}\right)$. The relationship between average daily $S F$ of the eight sample trees and DBH was determine by a linear equation $\left(S F=8.38 \mathrm{DBH}-158.48, R^{2}=0.92\right)$ as described by Shen et al. (2014). This relationship was used to calculate $S F$ for all other trees in the plot and determine $E_{c}$ as follows:

$E_{c}=\frac{\sum_{i=1}^{n} S F_{i}}{A_{c}}$

where $S F_{i}$ is the sap flux of $i$ th trees $\left(\mathrm{kg} \mathrm{day}^{-1}\right)$ in the plot, and $A_{c}$ is the crown projected area of the plot $\left(\mathrm{m}^{2}\right)$.

The determination of meteorological variables including solar radiation, air temperature, relative humidity, wind speed, atmospheric pressure, precipitation, saturated vapor pressure and vapor pressure deficit and reference evapotranspiration were given in Appendix A. The estimation of canopy conductance was described in Appendix B. The measurement of soil water content and groundwater table was provided in Appendix C.

\subsection{Estimation of groundwater evapotranspiration with the White method}

White (1932) proposed a method to estimate daily groundwater use by vegetation via evapotranspiration from the analysis of diurnal water table fluctuation (Fig. 1). The White method is used under the condition that groundwater is the dominant source for plant water use, and water table displays diurnal fluctuations in response to daily patterns of plant water use (White, 1932;

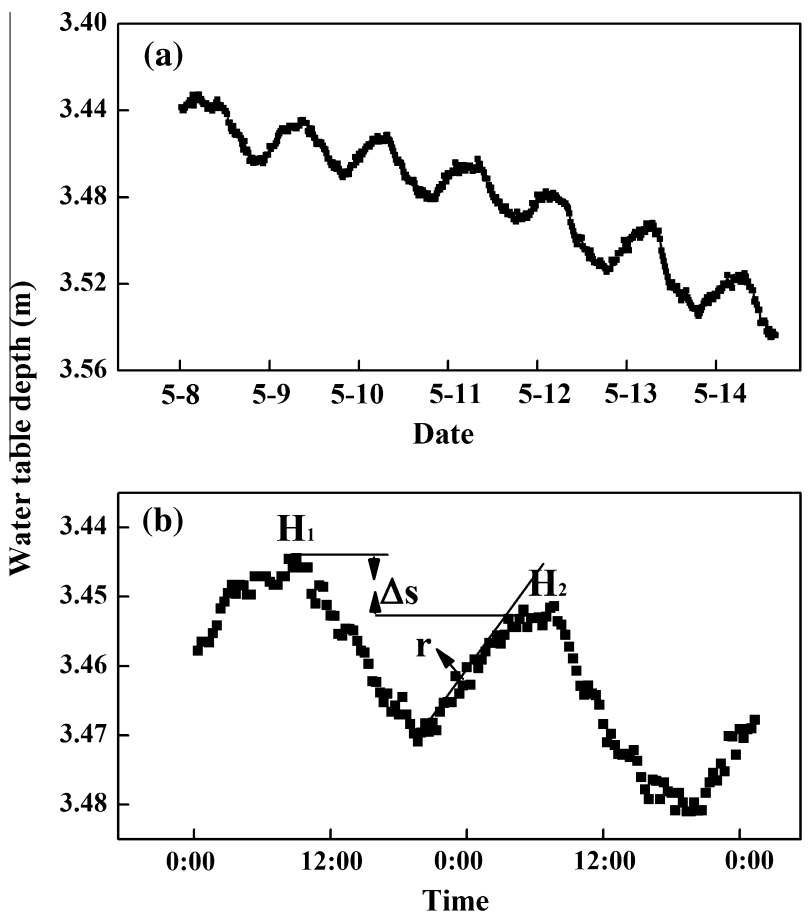

Fig. 1. Diurnal pattern of water table fluctuation: (a) 7-day sample period, and (b) basic principle of groundwater evapotranspiration estimation using the White method.
Loheide et al., 2005). Furthermore, evapotranspiration is assumed to be negligible relative to the groundwater inflow between midnight and 4 a.m., and the net inflow of groundwater is constant throughout the day (White, 1932; Loheide et al., 2005). The average daily groundwater evapotranspiration $\left(\mathrm{ET}_{g}, \mathrm{~mm} \mathrm{day}^{-1}\right)$ based on the White method was calculated as follows:

$\mathrm{ET}_{g}=(24 r+\Delta h) \cdot S_{y}$

$\Delta h=\left(-H_{1}\right)-\left(-H_{2}\right)$

where $r$ is the net inflow rate between midnight and 4 a.m. $\left(\mathrm{m} \mathrm{h}^{-1}\right)$, $\Delta h$ is the net rise or fall of water table during 24 -h period $\left(\mathrm{m} \mathrm{day}^{-1}\right)$, and $S_{y}$ is the specific yield (-). The net inflow rate is calculated from the slope of the best fit line to the hydrograph between midnight and 4 a.m. (Fig. 1). The value of $\Delta h$ is the difference between $H_{1}$ and $H_{2}$, where $H_{1}$ is the peak of water table in the target day (m) and $H_{2}$ is the peak of the following day (m) (Fig. 1). When soil texture is homogeneous and the water table depth is more than $1 \mathrm{~m}$ for duration of drainage less than $12 \mathrm{~h}, S_{y}$ is estimated as follows (Loheide et al., 2005).

$S_{y}=\varphi-S_{r}$

where $\varphi$ is porosity $\left(\mathrm{cm}^{3} \mathrm{~cm}^{-3}\right)$ that is determined by the saturated soil water content, and $S_{r}$ is soil specific retention $\left(\mathrm{cm}^{3} \mathrm{~cm}^{-3}\right)$ that is defined as the soil water content at which soil water cannot be drained by gravity, and it is equal to field capacity.

\section{Results}

\subsection{Environmental variables}

Over the three consecutive growing seasons, there were no noticeable differences in air temperature, relative humidity, and vapor pressure deficit. Air temperature, solar radiation, and vapor pressure deficit showed obvious seasonal trends and the maximum values occurred in July or August (Fig. 2). In 2012, the average daily air temperature was $19.4{ }^{\circ} \mathrm{C}$ with the highest temperature $\left(29.0^{\circ} \mathrm{C}\right)$ having been recorded in August and the lowest $\left(3.3^{\circ} \mathrm{C}\right)$ in April. In 2013 , the average daily air temperature was $19.1^{\circ} \mathrm{C}$ with the highest temperature $\left(27.6^{\circ} \mathrm{C}\right)$ in August and the lowest $\left(2.3^{\circ} \mathrm{C}\right)$ in April. In 2014 , the average daily air temperature was $18.7^{\circ} \mathrm{C}$ with the highest temperature $\left(28.8^{\circ} \mathrm{C}\right)$ in July and the lowest $\left(6.8^{\circ} \mathrm{C}\right)$ in April (Fig. 2a). The average daily relative humidity was $39 \%$ in $2012,41 \%$ in 2013 , and $41 \%$ in 2014 , showing no apparent trend (Fig. 2b). The average daily solar radiation was $22.1 \mathrm{MJ} \mathrm{m}^{-2}$ in 2012, $20.3 \mathrm{MJ} \mathrm{m}^{-2}$ in 2013, and $20.8 \mathrm{MJ} \mathrm{m}^{-2}$ in 2014 (Fig. 2c). The average daily vapor pressure deficit was $1.4 \mathrm{kPa}$ in $2012,1.4 \mathrm{kPa}$ in 2013 , and $1.3 \mathrm{kPa}$ in 2014, with the highest values having been recorded in August 2012 (2.72 kPa), June 2013 (2.65 kPa), and June 2014 (3.07 kPa) (Fig. 2d). The reference evapotranspiration showed similar trend with the vapor pressure deficit and solar radiation (Fig. 2e). The average daily reference evapotranspiration was $4.7 \mathrm{~mm}$ in 2012, $4.8 \mathrm{~mm}$ in 2013, and $4.8 \mathrm{~mm}$ in 2014. The highest daily reference evapotranspiration values were recorded on August 3 in 2012 (6.9 mm), June 26 in 2013 (7.2 mm), and July 17 in 2014 (7.6 mm), while the lowest values on April 11 in $2012(1.8 \mathrm{~mm})$, August 17 in $2013(1.9 \mathrm{~mm})$, and September 27 in $2014(2.2 \mathrm{~mm})$.

The precipitation level in $2013(105.6 \mathrm{~mm})$ was higher than that in 2012 (95.8 $\mathrm{mm}$ ) and 2014 (93.4 mm). Weak precipitation events ( $5 \mathrm{~mm}$ or less) were frequent, while strong precipitation events (more than $10 \mathrm{~mm}$ ) were infrequent. Weak precipitation events accounted for $73 \%$ of total events and $28 \%$ of total precipitation amount in 2012. The corresponding proportions were $84 \%$ and $34 \%$ in 2013 , and $82 \%$ and $47 \%$ in 2014 . Strong precipitation events accounted for $12 \%$ of total events and $44 \%$ of total precipitation 


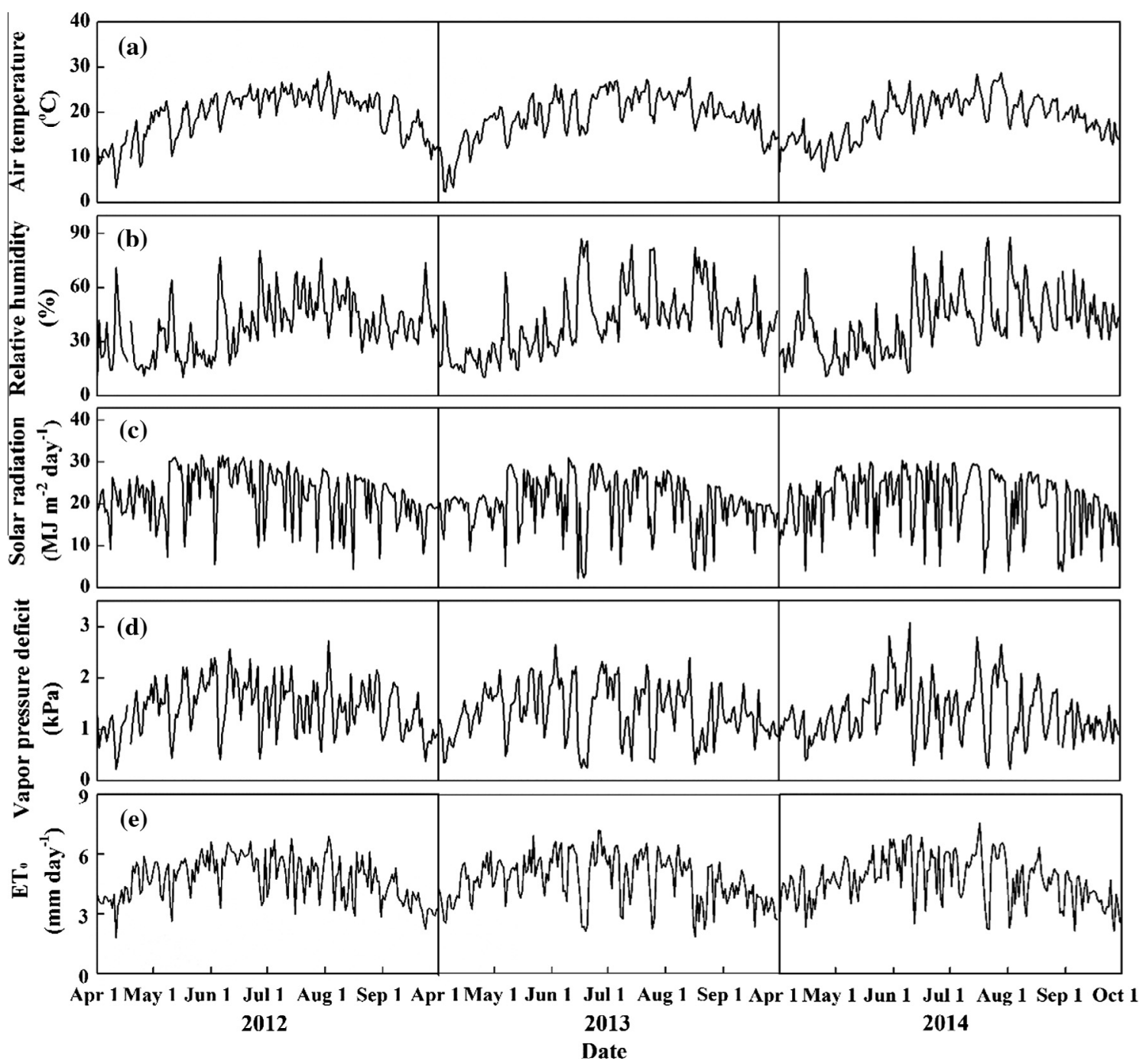

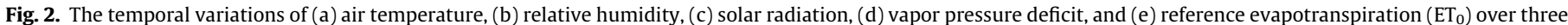
consecutive growing seasons (2012-2014).

amount in 2012. The corresponding proportions were $6 \%$ and $46 \%$ in 2013 , and $3 \%$ and $20 \%$ in 2014 . The strongest precipitation events occurred on June 5 in 2012 (16.2 mm), July 14 in 2013 (30.6 mm), and July 22 in 2014 (18.8 mm). Approximately $70 \%$ of total precipitation events occurred in June and July (Fig. 3a).

The temporal variations of soil water content above $220 \mathrm{~cm}$ depth were shown in Fig. $3 \mathrm{~b}$. The soil water content at the 0 $220 \mathrm{~cm}$ layer showed distinct pulses in response to irrigation and strong precipitation events, whereas it was in a water deficit condition at all other times. Soil water content decreased gradually from the beginning of the growing season until the irrigation event that increased steeply, and then decreased again with some fluctuations after the precipitation events. The threshold of soil water content deficit at the $0-220 \mathrm{~cm}$ layer was $6.4 \%$ with the relative extractable water less than 0.4 . It was noted that trees hardly absorbed water from the unsaturated zone during the soil water deficit periods. Soil water content at the $220-280 \mathrm{~cm}$ layer was always higher than field capacity (20.4\%), due to the influence of groundwater recharge (Fig. 3c).

Water table depth fluctuated with the seasonal streamflow variations of the Heihe River and irrigation events during the growing season (Fig. 3d). Temporal variations of the water table depth were similar among the three growing seasons. The water table depth usually was lower at the beginning of the growing season, then reached its peak value after irrigation, and subsequently decreased to the lowest value at the end of the growing season with some fluctuations. The peak value of water table depth was $2.9 \mathrm{~m}$ on June 28 in 2012, $2.9 \mathrm{~m}$ on May 20 in 2013, and $2.8 \mathrm{~m}$ on June 16 in 2014. The water table depth at the end of the growing season was $3.9 \mathrm{~m}$ in 2012, $3.6 \mathrm{~m}$ in 2013, and $3.6 \mathrm{~m}$ in 2014 (Fig. 3d).

\subsection{Diurnal variation of stand transpiration and canopy conductance}

The diurnal variations of solar radiation, vapor pressure deficit, stand transpiration, and canopy conductance under dry $($ REW $<0.4)$ and wet $($ REW $>0.4)$ soil conditions, were shown in Fig. 4. The diurnal variations of stand transpiration and canopy conductance followed a unimodal pattern (Fig. 4). The maximum canopy conductance occurred earlier $(09: 00 \mathrm{~h})$ than the maximum stand transpiration (13:00-14:00 h). The diurnal course of stand transpiration was closely related to the changes of vapor pressure deficit and solar radiation (Fig. 4). The maximum stand transpiration was observed concurrently with the maximum solar radiation, but slightly earlier than the maximum vapor pressure deficit, as evident from Fig. 4.

Stand transpiration and canopy conductance increased significantly ( $t$-test, $p<0.05$ ) when soil water condition changed from dry to wet. The average daily stand transpiration was $5.1 \pm 0.7 \mathrm{~mm}$ and $6.5 \pm 0.5 \mathrm{~mm}$ under dry and wet soil conditions, 


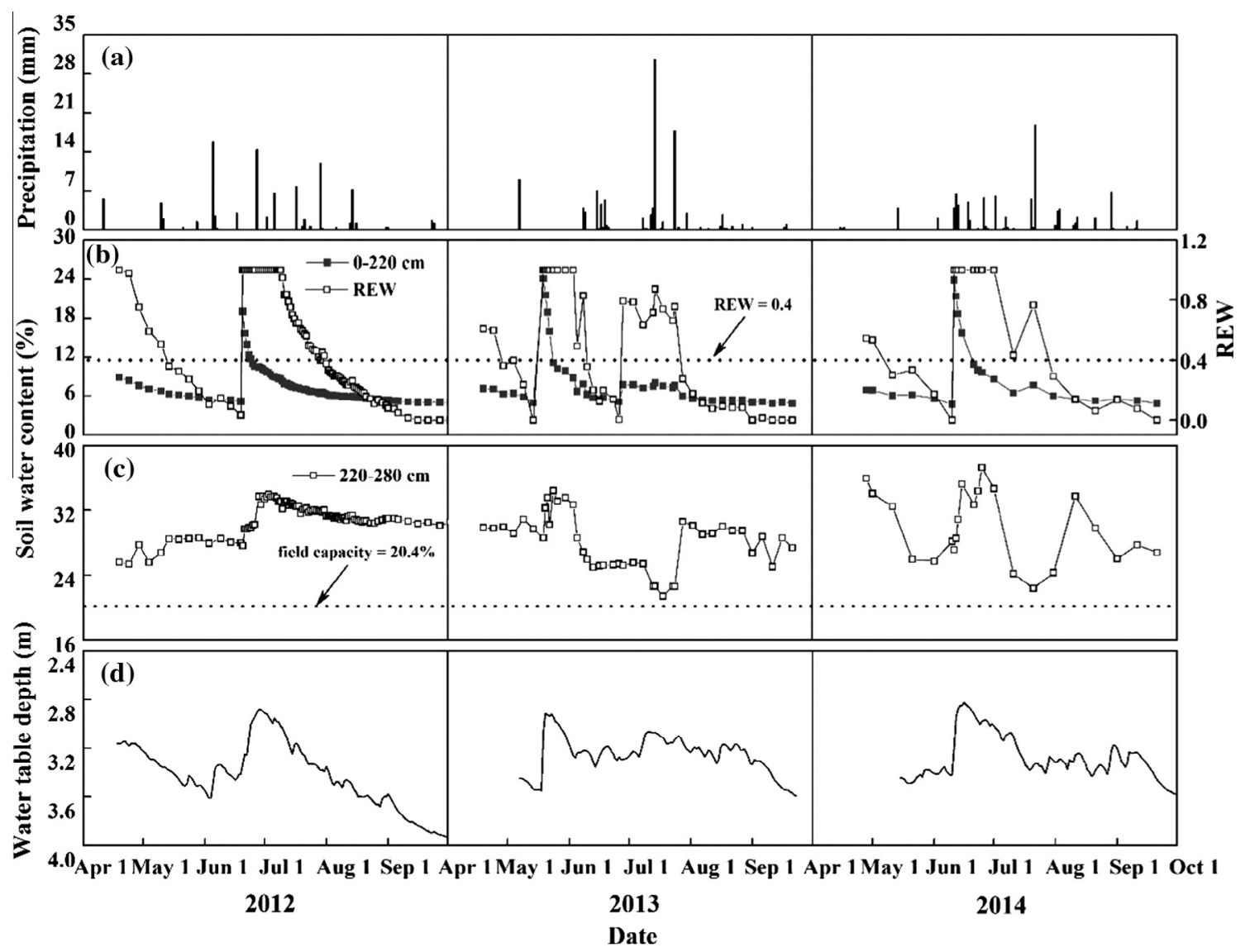

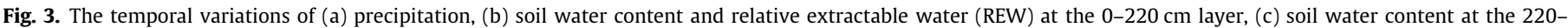
$280 \mathrm{~cm}$ layer, and (d) water table depth over three consecutive growing seasons (2012-2014).
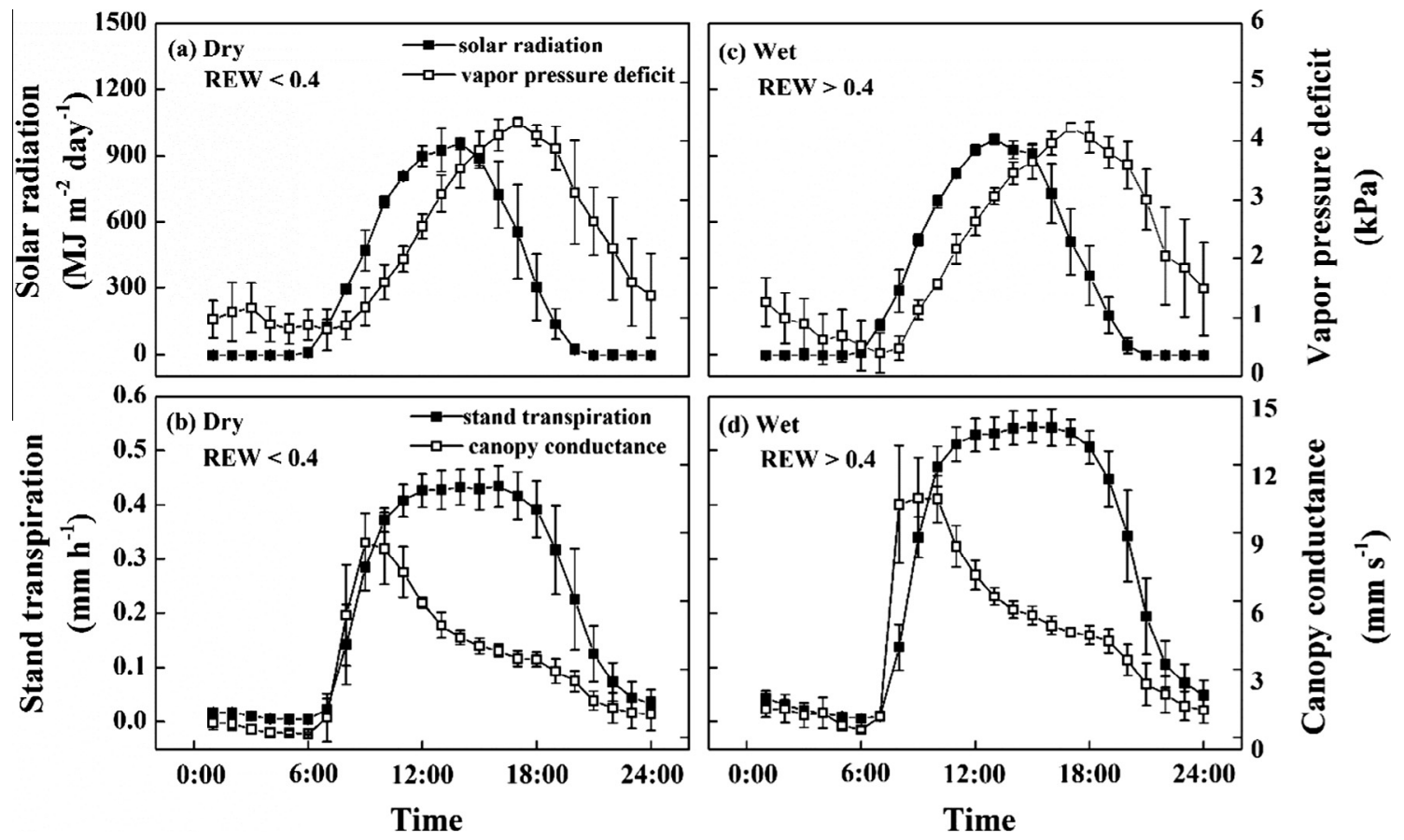

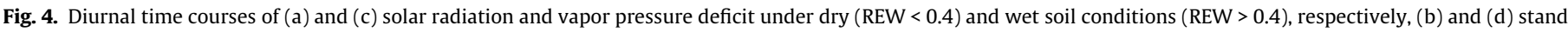
transpiration and canopy conductance under dry and wet soil conditions, respectively. Data represent means \pm standard deviation $(n=5)$. 

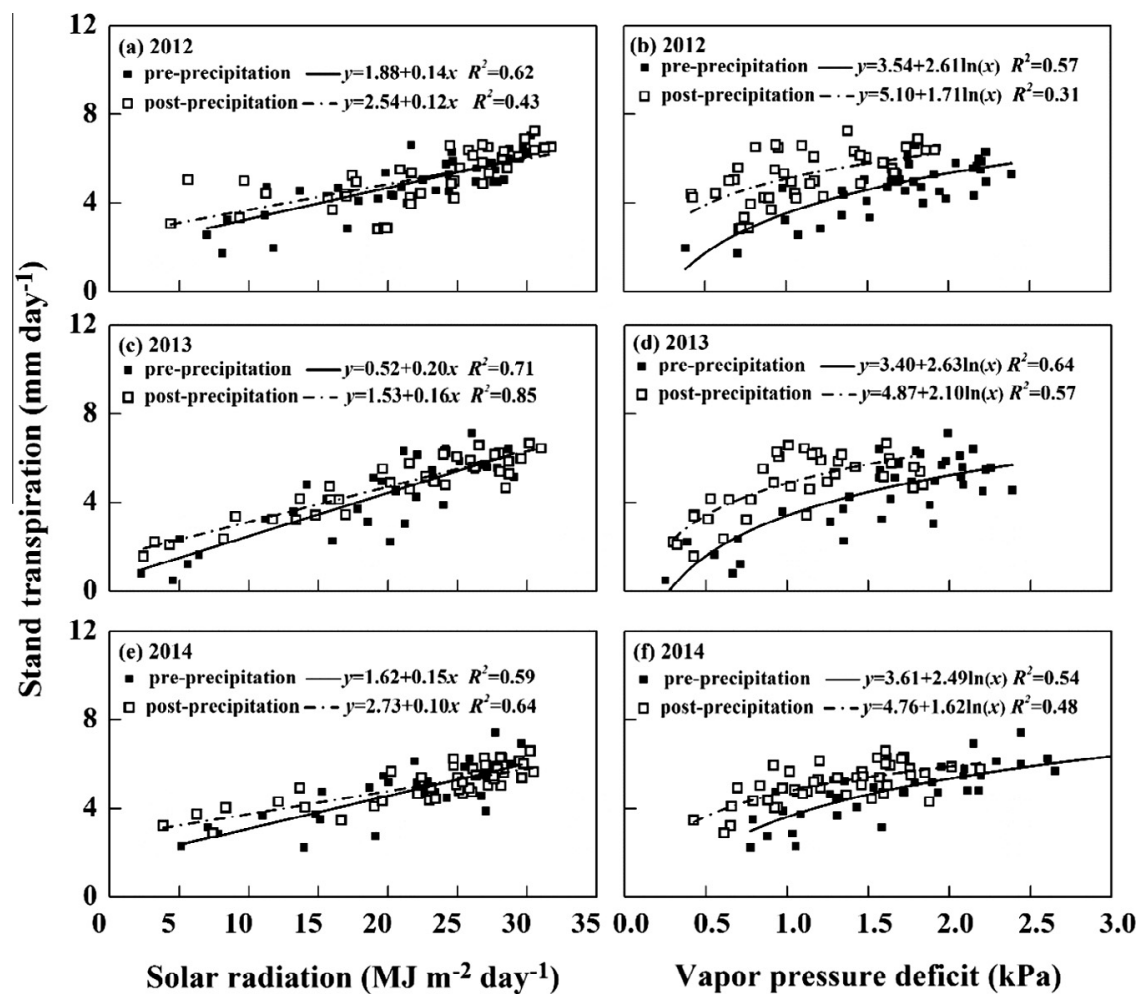

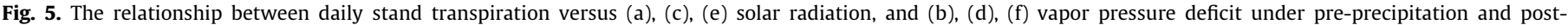
precipitation periods over three consecutive growing seasons (2012-2014).

respectively. The average daytime canopy conductance increased from $4.9 \pm 0.4 \mathrm{~mm} \mathrm{~s}^{-1}$ under dry soil conditions to $6.4 \pm 0.5 \mathrm{~mm} \mathrm{~s}^{-1}$ under wet soil conditions (Fig. 4).

\subsection{Comparison of stand transpiration during pre-precipitation and post-precipitation periods}

The sensitivity of Gansu Poplar stand transpiration to atmospheric drought was investigated by evaluating the effect of precipitation on stand transpiration. The relationship of stand transpiration with solar radiation and vapor pressure deficit during the pre-precipitation and post-precipitation periods was shown in Fig. 5. Stand transpiration was linearly related to solar radiation and logarithmically related to vapor pressure deficit. The average daily pre-precipitation stand transpiration was $4.8 \pm 1.2 \mathrm{~mm}$ in $2012,4.4 \pm 1.7 \mathrm{~mm}$ in 2013 , and $4.8 \pm 1.2 \mathrm{~mm}$ in 2014 , whereas the average post-precipitation stand transpiration was $5.2 \pm 1.2 \mathrm{~mm}$ in 2012, $4.8 \pm 1.4 \mathrm{~mm}$ in 2013 , and $5.1 \pm 0.9 \mathrm{~mm}$ in 2014 (Fig. 6). The post-precipitation stand transpiration increased by $8 \%$ in $2012,9 \%$ in 2013 , and $6 \%$ in 2014 compared to the preprecipitation stand transpiration. However, the increase was not statistically significant in any year (paired $t$-test, $p>0.05$ ) (Fig. 6). The average daily $\mathrm{ET}_{0}$ during the pre-precipitation periods was $5.0 \pm 1.2 \mathrm{~mm}$ in 2012, $5.2 \pm 1.2 \mathrm{~mm}$ in 2013 , and $5.2 \pm 1.1 \mathrm{~mm}$ in 2014, whereas during the post-precipitation periods it was $4.7 \pm 1.0 \mathrm{~mm}$ in $2012,4.6 \pm 1.4 \mathrm{~mm}$ in 2013 , and $5.2 \pm 1.0 \mathrm{~mm}$ in 2014. $\mathrm{ET}_{0}$ during the post-precipitation periods was lower or similar to that during the pre-precipitation periods.

\subsection{Comparison of canopy conductance under wet and dry soil conditions}

The relationship of canopy conductance with solar radiation and vapor pressure deficit under wet and dry conditions was

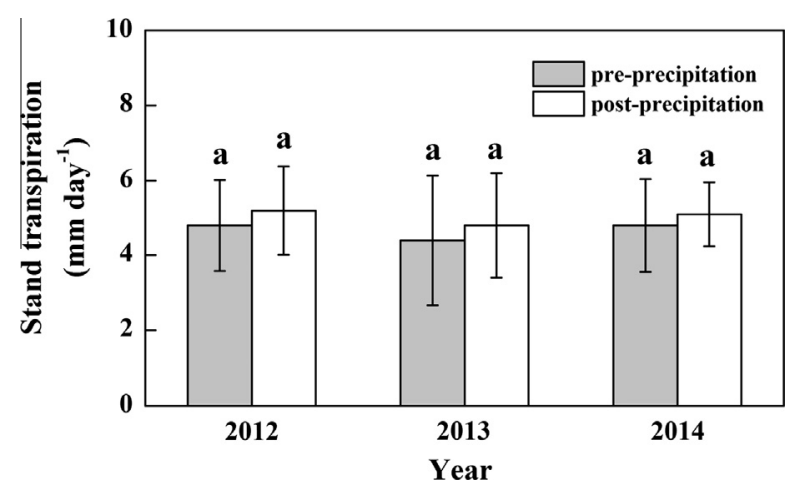

Fig. 6. Comparison of average daily stand transpiration between pre-precipitation and post-precipitation periods over three consecutive growing seasons (20122014). The error bars stands for standard deviation, and same lowercase letters indicate no significant differences (paired $t$-test, $p>0.05$ ).

shown in Fig. 7. The canopy conductance decreased logarithmically with vapor pressure deficit (Fig. $7 \mathrm{~b}, \mathrm{~d}$ and f), while no apparent relationship was identified between canopy conductance and solar radiation (Fig. 7a, c and e). At a given vapor pressure deficit, canopy conductance as well as the stomatal sensitivity response to vapor pressure deficit, were higher under wet soil conditions than those under dry soil conditions. The soil water conditions had significant effect on canopy conductance.

\subsection{Comparison of groundwater evapotranspiration and stand transpiration}

Stand transpiration was negatively correlated to water table depth (Fig. 8 ) $(p<0.05)$, and groundwater had an important effect on stand transpiration, especially during the soil water deficit per- 

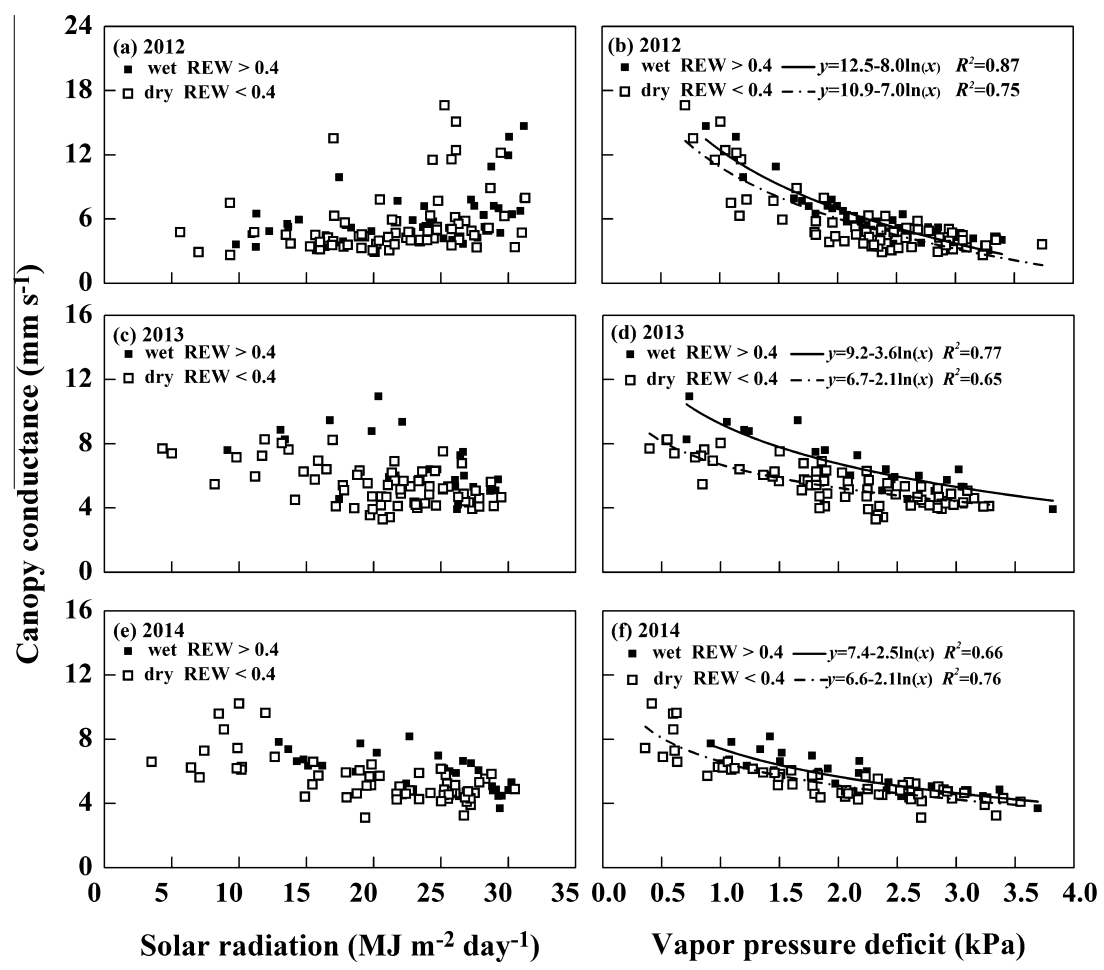

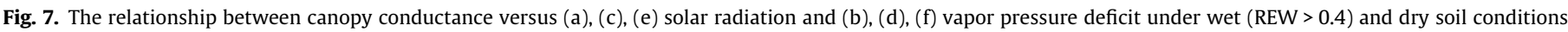
$($ REW $<0.4)$ over three consecutive growing seasons $(2012-2014)$.

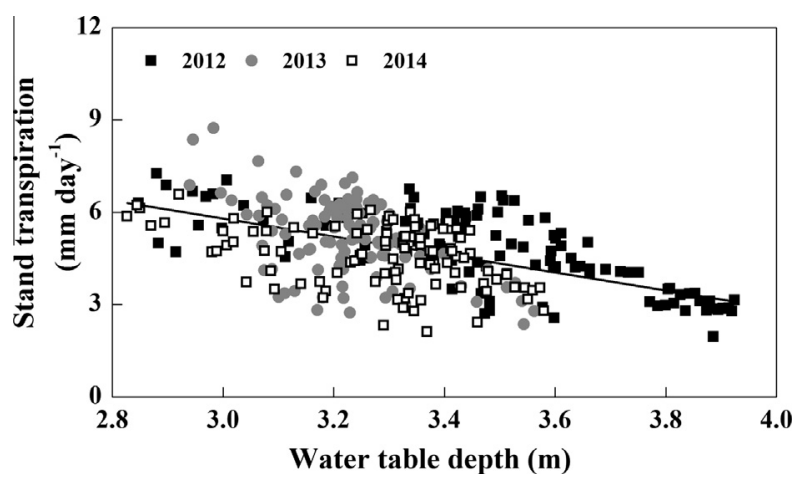

Fig. 8. The relationship between stand transpiration versus water table depth over three consecutive growing seasons (2012-2014).

iod. The White method was applied under the condition that groundwater was the dominant source for tree transpiration during the soil water drought period (with REW $<0.4$ in Fig. 3b). Strong diel fluctuation in water table depth was evident over the three consecutive growing seasons, except for the days with irrigation and strong precipitation events which were excluded for groundwater evapotranspiration calculation. A readily available specific yield of 0.1 was used, resulting in the range of groundwater evapotranspiration estimates from $0.6 \mathrm{~mm}$ to $7.1 \mathrm{~mm}^{-1} \mathrm{day}^{-1}$ under the dry soil conditions plotted in Fig. 9. For comparison, stand transpiration estimated by the sap flow method ranged from 1.1 to $6.5 \mathrm{~mm}$ day $^{-1}$. Groundwater evapotranspiration was linearly correlated with stand transpiration $\left(R^{2}=0.71\right)$, and these two variables had similar variability (Fig. 9). Groundwater evapotranspiration accounted for about $80 \%$ of stand transpiration during the drought periods.

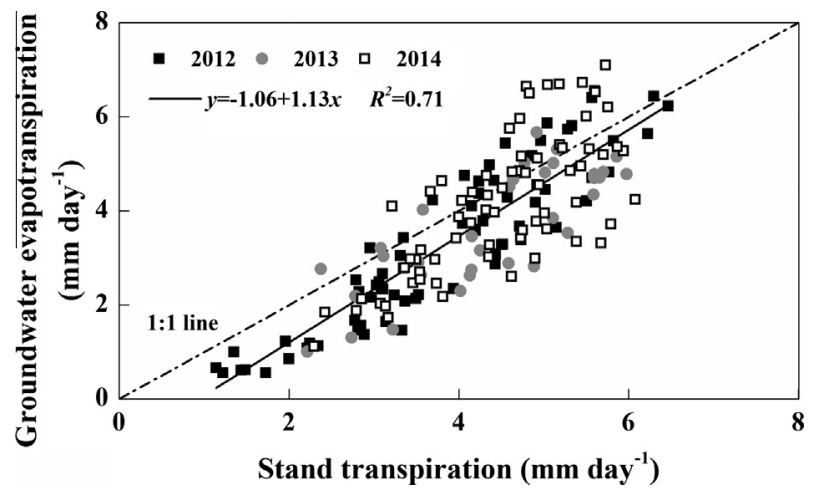

Fig. 9. Comparison of daily groundwater evapotranspiration with stand transpiration over three consecutive growing seasons (2012-2014).

\section{Discussion}

\subsection{Effect of precipitation, soil water and groundwater on stand} transpiration

Gansu Poplar trees had a higher stand transpiration rate after precipitation than pre-precipitation under similar vapor pressure deficit and solar radiation conditions, indicating lower resistance to transpiration flux and higher to canopy conductance (Fig. 5). The reference evapotranspiration decreased after precipitation, suggesting that the increases of stand transpiration after precipitation was not caused by changes in the potential evapotranspiration, but due to precipitation. A previous study that investigated the interannual variability of transpiration in a Scots pine (Pinus sylvestris) forest located in a montane area of the Eastern Pyrenees showed that there was a 25\% decrease in transpiration in 2003 compared to 2004, since precipitation during the summer of 2003 was almost 40\% less than that in 2004 (Poyatos et al., 
2005). Similar results were reported for a Quercus ilex forest in southern France, where the reduced precipitation by $29 \%$ caused a reduction in the annual transpiration by $23 \%$ (Limousin et al., 2009). Strong precipitation events could lower surface-atmosphere vapor pressure deficit and increase plant water potential. These seasonal changes in microclimate and physiology were considered as the cause of the high increase in stand transpiration. Vourlitis et al. (2002) observed that seasonal variation in the average midday surface conductance was positively correlated with precipitation, and the vapor pressure deficit had an influence on canopy conductance.

Precipitation increased not only the leaf water potential but also the soil water content and transpiration rate. A study on the transpiration of mature forests in a floodplain and an upland site showed that the floodplain forest had a similar transpiration rate with the upland site forest during the rainy season when the number of wet and cloudy days with low vapor pressure deficit was high (Oren et al., 1996). However, transpiration in the upland site forest was only $55-65 \%$ of that in the floodplain forest during the pronounced dry season in which precipitation was infrequent and vapor pressure deficit was often high (Oren et al., 1996). These results indicate that precipitation can offset water stress on forest transpiration.

Soil water conditions were the dominant factor influencing hydraulic conductance (Addington et al., 2004). Temporal recharge of soil water by precipitation or irrigation caused an increase in stand transpiration due to the release of xylem hydraulic conductance (Eberbach and Burrows, 2006). In this study, the sensitivity of canopy conductance response to vapor pressure deficit decreased under dry soil conditions (Fig. 7). Soil drought had a negative effect on hydraulic conductance and decreased canopy conductance. Other factors, including leaf area expansion (Oren et al., 2001), proportion change in the latewood and earlywood (Domec and Gartner, 2002) and chemical signaling (Wilkinson and Davies, 2002), might play important roles in the stomatal conductance response to changes in vapor pressure deficit and soil water content.

A characteristic exponential decrease in canopy conductance with increasing vapor pressure deficit was observed, and no distinguished relationship between canopy conductance and solar radiation was identified (Fig. 7). Canopy conductance response to increasing vapor pressure deficit occurred to prevent any highly negative values of leaf water potential and the subsequent xylem cavitation (Addington et al., 2004). The sensitivity of the canopy conductance response to vapor pressure deficit was related to maximum canopy conductance at low vapor pressure deficit (Oren et al., 1999). Addington et al. (2004) suggested that canopy conductance response to vapor pressure deficit might have a strong correlation with hydraulic conductance along the soil-toleaf pathway. Hydraulic conductance controlled the maximum canopy conductance, and affected the sensitivity of the response to increasing vapor pressure deficit. A study on the effect of water deficits on the water use of citrus trees in a semi-arid environment demonstrated that water restriction reduced the transpiration rate of water stressed treatment up to $60 \%$ compared to that of the well-irrigated treatment at the peak of water stress (Roccuzzo et al., 2014).

Atmospheric drought and soil drought had negative effects on canopy conductance and stand transpiration. The Gansu Poplar stand mostly grew under dry soil conditions due to scarce precipitation and irrigation events. Precipitation and irrigation water amounts were not enough for stand transpiration. However, the Gansu Poplar stand did not show extensive leaf senescence and abscission. The results indicated that Gansu Poplar trees could get access to other water resources. Over the three growing seasons, the water table depth was less than $4 \mathrm{~m}$, with a minimum value at $2.8 \mathrm{~m}$, while the roots of Gansu Poplar trees were deeper than $3.2 \mathrm{~m}$ (Shen et al., 2014). Groundwater recharged the transpiration of Gansu Poplar trees, which was shown by the negative relationship between stand transpiration and water table depth (Fig. 8). Similar result was found in Populus euphratica in the middle and lower reaches of the Tarim River (Ma et al., 2013). However, the study by Gazal et al. (2006) presented that lower rates of transpiration were found at the intermittent stream site, whereas it was not observed at the perennial stream site. The degree of groundwater utilized by the study species was dependent on the proximity of groundwater, availability of soil water in shallower soil layers, root system distribution and maximum root depth.

\subsection{Applicability of the White method to estimate groundwater evapotranspiration}

The White method is one of the most widely applied methods for calculating the water use of phreatophytes due to the abundant data available and its simplicity for estimating recharge rate from temporal fluctuations of water table depth (Healy and Cook, 2002). In this study, groundwater evapotranspiration estimated from the White method showed similar variation with stand transpiration. The groundwater evapotranspiration had a good linear relationship with stand transpiration $\left(R^{2}=0.71\right)$ (Fig. 9). The high correlation between groundwater evapotranspiration and stand transpiration demonstrated that the application of the White method for estimating water use of Gansu Poplar shelterbelt was reasonable under the dry soil conditions. During the drought periods, the groundwater uptake estimated by the White method was approximately $80 \%$ of stand transpiration estimated by the sap flow method. Similar results were obtained in a study of Eucalyptus camaldulensis in the Pampas grasslands of Argentina (Engel et al., 2005) and deciduous blue oak trees ( $Q$. douglasii) in a California oak savanna (Miller et al., 2010).

The White method has been also applied to compare the water use of different vegetation types. Schilling (2007) showed that daily groundwater evapotranspiration of forest cover was higher than that of grass and corn in riparian zones, with peak evapotranspiration in July ranging from 5.02 to $6.32 \mathrm{~mm} \mathrm{day}^{-1}$ for forest cover and from 1.81 to $4.13 \mathrm{~mm} \mathrm{day}^{-1}$ for corn and grass. Wang et al. (2014) found that the estimated groundwater evapotranspiration ranged from 0.63 to $0.73 \mathrm{~mm} \mathrm{day}^{-1}$ at the Tamarix ramosissima site and from 1.89 to $2.33 \mathrm{~mm} \mathrm{day}^{-1}$ at the $P$. euphratica site during the summer months in the lower reach of Heihe River Basin characterized by an extreme arid environment.

However, the application of the White method, based on the analysis of diurnal water fluctuations, might involve a high degree of uncertainty in the estimation of the daily groundwater evapotranspiration. Previous studies indicated that groundwater evapotranspiration estimated by the White method was higher than that obtained by the sap flow method (Wang et al., 2014), and lower than that by the eddy covariance method (Martinet et al., 2009). Considering the principal assumptions of the White method, the determination of the net inflow or recovery rate (Miller et al., 2010) and the estimation of the readily available specific yield (Loheide et al., 2005) increased the uncertainty in the calculation of groundwater evapotranspiration. The net inflow or recovery rate was estimated as the rate of change in the water table during a period with negligible plant transpiration between $00: 00 \mathrm{~h}$ and 04:00 h, as proposed by White (1932), which should be modified to a more convenient time frame (Mazur et al., 2014). Furthermore, 
specific yield was calculated with a constant value of 0.1 , and the effects of water table variations and sediment properties on specific yield should be substantially incorporated (Loheide et al., 2005).

\subsection{Contributions and implications of this study}

The main novelty of this study is to combine the sap flow measurements with diurnal water table fluctuation method to comprehensively investigate the integrated effects of drought condition (precipitation and soil water) and groundwater variation on shelterbelt stand transpiration in the arid inland river basin. Furthermore, the White method has been applied in floodplains (Engel et al., 2005), riparian zones (Martinet et al., 2009), wetlands (Mazur et al., 2014) and desert areas (Cheng et al., 2013) to estimate groundwater transpiration. However, the application of this method has not been used for estimation of the shelterbelt transpiration. The comparison with the measured stand transpiration in this study indicated that the application with the White method to estimate the plant transpiration could be considered in similar shelterbelt of arid area, where the groundwater is the dominant source for plant water use.

Water table variation is affected by the phreatophyte water use especially in arid areas. A decrease in the water table depth, due to the over-exploration of groundwater resources, can threaten the survival of the shelter-belt stands. As reported by Amlin and Rood (2003), Populus balsamifera displayed extensive leaf senescence and abscission with the decreasing water table depth. Similar morphological and physiological responses to groundwater depletion have been also reported for Populus deltoids (Cooper et al., 2003). The increasing scarcity of water resources in arid areas has led to the increased extraction of groundwater. Overexploitation and severe waste of water resources have long been a problem in the Northwest China because of the lack of rational planning and effective water-saving measures and thus cause a series of ill-effects on the hydrological regime and ecological environment (Wang and Cheng, 2000), i.e., the survival of shelterbelt tree stands, which influences the sustainability of oasis ecosystems. This study showed that soil water had a great influence on the plant transpiration, whereas, there was only one flood irrigation event during the growing season, and more frequency with less amount irrigation should be conducted.

Due to the less precipitation and dry soil water, shelterbelt transpiration from the groundwater accounted for approximately $80 \%$ during the drought periods. Gou and Miller (2014) found that the water source for transpiration in a blue oak stand $(Q$. douglasii) in a California savanna turned from soil water in the wet season to groundwater in the dry season. Similar results had been found in a Scots pine stand ( $P$. sylvestris) in a sandy soil with shallow water table that the contribution of groundwater to transpiration from May to November reached $61 \%$, while the groundwater contributed to $98.5 \%$ during the drought period in June (Vincke and Thiry, 2008), and in a cork oak woodland (Quercus suber) in the Mediterranean region where the yearly groundwater contribution to tree transpiration occupied by $30.3 \%$, while groundwater uptake accounted for $72.3 \%$ in dry summer (Pinto et al., 2014). The critical role of groundwater is especially significant for shelterbelt under dry conditions.

Groundwater is so important to shelterbelt transpiration that the understanding of the shelterbelt response to relatively small changes in water table depth under the dry conditions is essential. As discussed by Cooper et al. (2006) that drought tolerant plant species might survive for decades under conditions of a declining water table with only reduced leaf area, while other plants might experience a significant canopy dieback or death. Further studies should focus on the plant water use strategy under declining groundwater and find the threshold of the water table for main- taining the healthy growth of the shelterbelt to exert the ecological value of wind prevention and sand-fixation. In this regard, this study could provide the basis for the development of water requirement schemes for shelterbelt growth in arid inland river basin.

\section{Conclusions}

In this study, the daily stand transpiration of eight Gansu Poplar trees (P. Gansuensis) and the groundwater variation were studied over three consecutive growing seasons (2012-2014). The effects of precipitation, soil water condition, and groundwater variation on Gansu Poplar stand transpiration and canopy conductance were investigated. Precipitation had a positive effect on stand transpiration, but the increase was not statistically significant (paired $t$-test, $p>0.05$ ). Soil water had a significant positive effect on stand transpiration and canopy conductance ( $t$-test, $p<0.05$ ). The average daily stand transpiration increased from $5.1 \pm 0.7 \mathrm{~mm}$ to $6.5 \pm 0.5 \mathrm{~mm}$, and the canopy conductance increased from $4.9 \pm 0.4 \mathrm{~mm}$ to $6.4 \pm 0.5 \mathrm{~mm}$, when soil water conditions changed from dry to wet. Canopy conductance decreased logarithmically with vapor pressure deficit, but no relationship between canopy conductance and solar radiation was identified. Soil drought decreased the sensitivity of canopy conductance to vapor pressure deficit. Groundwater evapotranspiration estimated by the White method using diurnal water table fluctuations was linearly correlated with stand transpiration $\left(R^{2}=0.71\right)$. Groundwater uptake due to plant transpiration accounted for $80 \%$ of the total stand transpiration during the soil drought period. The application of the White method for estimating shelterbelt stand transpiration from groundwater evapotranspiration in similar ecosystems was considered reasonable during the drought periods, because of the deep root distribution and dry climate with low precipitation levels. However, the White method suffers from a variety of errors, primarily due to the uncertainty in determining the net inflow or recovery rate and the estimating the readily available specific yield. The accurate quantification of groundwater contribution to stand transpiration is considered essential in ecosystem management and water resources distribution in arid inland river basin.

\section{Acknowledgements}

This research was financially supported by the National Natural Science Foundation of China (91025018, 91425301 and 91025002), and the 12th Five Year Science and Technology Development Program (2012BAC08B01). We would like to thank the Linze Inland River Basin Research Station Experimental for field experiment support. We thank the associate editor and reviewer for their constructive comments which improve the quality of this manuscript.

\section{Appendix A. Meteorological variables}

Solar radiation, air temperature, relative humidity, wind speed, atmospheric pressure and precipitation were measured by an AG1000 automatic weather station (Onset Computer Corporation, Pocasset, MA, USA) located $300 \mathrm{~m}$ from the study site. The meteorological data were recorded at 5-min intervals with a CR1000 data logger (Campbell Scientific Inc., Logan, UT), and stored every $30 \mathrm{~min}$ on average, except for precipitation and wind data that were stored every $10 \mathrm{~min}$.

The saturated vapor pressure $\left(e_{s}, \mathrm{kPa}\right)$ was calculated as follows:

$e_{s}=0.611 \exp \left(\frac{17.27 T_{a}}{237.3+T_{a}}\right)$

where $T_{a}$ is air temperature $\left({ }^{\circ} \mathrm{C}\right)$. 
The vapor pressure deficit (VPD, $\mathrm{kPa}$ ) was the difference between the saturated vapor pressure and actual vapor pressure $\left(e_{a}, \mathrm{kPa}\right)$ :

$\mathrm{VPD}=e_{s}-e_{a}$

The daily reference evapotranspiration $\left(\mathrm{ET}_{0}, \mathrm{~mm}\right)$ was calculated using the FAO 56 Penman-Monteith equation (Allen et al., 1998):

$\mathrm{ET}_{0}=\frac{0.408 \Delta\left(R_{n}-G\right)+\gamma \frac{900}{T_{a}+273} u_{2} \mathrm{VPD}}{\Delta+\gamma\left(1+0.34 u_{2}\right)}$

where $\Delta$ is the slope vapor pressure curve $\left(\mathrm{kPa}^{\circ} \mathrm{C}^{-1}\right), R_{n}$ is the net radiation at the crop surface $\left(\mathrm{MJ} \mathrm{m}^{-2} \mathrm{day}^{-1}\right), G$ is the soil heat flux density $\left(\mathrm{MJ} \mathrm{m}^{-2}\right.$ day $\left.^{-1}\right), \gamma$ is the psychrometric constant $\left(\mathrm{kPa}^{\circ} \mathrm{C}^{-1}\right)$, and $u_{2}$ is the wind speed at $2 \mathrm{~m}$ height $\left(\mathrm{m} \mathrm{s}^{-1}\right)$.

\section{Appendix B. Canopy conductance}

Canopy conductance $\left(G_{c}, \mathrm{~m} \mathrm{~s}^{-1}\right)$ was calculated with the following simplified reverse form of the Penman-Monteith equation (Phillips and Oren, 1998):

$G_{c}=\frac{\gamma(T) \lambda\left(T_{a}\right) E_{c}}{C_{p} \rho\left(T_{a}\right) \mathrm{VPD}}$

$G_{c}=\frac{K_{g} E_{c}}{\mathrm{VPD}}$

$K_{g}=\frac{\gamma(T) \lambda\left(T_{a}\right)}{C_{p} \rho\left(T_{a}\right)}=115.8+0.4236 T_{a}$

where $\gamma$ is the psychrometric constant $\left(\mathrm{kPa} \mathrm{K}^{-1}\right), \lambda$ is the latent heat of vaporization of water $\left(\mathrm{J} \mathrm{kg}^{-1}\right), C_{p}$ is the specific heat of air ( $\left.\mathrm{J} \mathrm{kg}^{-1} \mathrm{~K}^{-1}\right), \rho$ is the density of liquid water $\left(\mathrm{kg} \mathrm{m}^{-3}\right)$, and $K_{\mathrm{g}}$ is the conductance coefficient as a function of temperature $\left(\mathrm{kPa} \mathrm{m}^{3} \mathrm{~kg}^{-1}\right.$ ).

Daytime (PAR $\geqslant 10 \mu \mathrm{mol} \mathrm{m} \mathrm{m}^{-2} \mathrm{~s}^{-1}$ ) data were used for calculating $G_{c}$. Daily VPD and $T_{a}$ was obtained by averaging the values over daytime hours, while $E_{c}$ was summed over $24 \mathrm{~h}$ and divided by daylight hours (Phillips and Oren, 1998). Calculation of $G_{c}$ was limited to $\mathrm{VPD} \geqslant 0.6 \mathrm{kPa}$, in order to minimize relative errors at less than 10\% (Ewers and Oren, 2000).

\section{Appendix C. Soil water content and groundwater table}

Soil water content $(\theta, \%)$ was monitored based on TDR (TRIMETDR-PICO-IPH-T3, Imko, Germany). Six Trime-TDR access tubes (4 cm diameter, polycarbonate) were installed with 4-m distance in the shelterbelt tree stand. The soil water content profile was measured at $20-\mathrm{cm}$ intervals to a depth of $2.8 \mathrm{~m}$ every 5 days. Additional measurements were made after precipitation or irrigation events. Soil water content was calibrated by the oven drying method. Soil water content used in the following analysis was the average value of the six Trime-TDR access tubes.

The soil moisture profile was divided into two layers (0-220 and $220-280 \mathrm{~cm}$ ) (Shen et al., 2014) and then sub-divided into 14 layers of $20 \mathrm{~cm}$ depth each that denoted as $d_{i}$, which was from $d_{1}(0-20 \mathrm{~cm})$ to $d_{14}(260-280 \mathrm{~cm})$. Soil water content at a given measurement time $t$ for the $0-220$ and $220-280 \mathrm{~cm}$ layers was calculated as follows:

$\theta_{0-220, t}=\frac{1}{11} \sum_{i=1}^{11} \theta_{d_{i}}, \quad \theta_{220-280, t}=\frac{1}{3} \sum_{i=12}^{14} \theta_{d_{i}}$

where $d_{i}$ is the $i$ th soil layer.
Relative extractable water (REW) was calculated as follows (Granier, 1987):

$\mathrm{REW}=\frac{\theta-\theta_{r}}{\theta_{f c}-\theta_{r}}$

where $\theta_{r}$ is the residual soil water content at $-1500 \mathrm{kPa}$ and $\theta_{f c}$ is the residual field capacity at $-33 \mathrm{kPa}$. The threshold of soil water deficit conditions $\left(\theta_{\text {thr }}\right)$ was determined at a REW of 0.4 . Dry soil conditions could be identified when $\theta$ was lower than $\theta_{t h r}$, calculated from the following equation:

$\theta_{\text {thr }}=0.4 \theta_{f c}+0.6 \theta_{r}$

Groundwater table depth was recorded automatically every 20 min by water lever logger (Hobo U20-001-04, Onset Computer Corporation, Bourne, USA) in the monitoring well. The resolution of the water table depth measurements was $0.14 \mathrm{~cm}$ with an uncertainty of $\pm 0.3 \mathrm{~cm}$.

\section{References}

Addington, R.N., Mitchell, R.J., Oren, R., Donovan, L.A., 2004. Stomatal sensitivity to vapor pressure deficit and its relationship to hydraulic conductance in Pinus palustris. Tree Physiol. 24 (5), 561-569.

Allen, R.G., Pereira, L.S., Raes, D., Smith, M., 1998. Crop evapotranspiration (guidelines for computing crop water requirements). FAO Irrigation and drainage paper 56, Rome, Italy.

Amlin, N.M., Rood, S.B., 2003. Drought stress and recovery of riparian cottonwoods due to water table alteration along Willow Creek, Alberta. Trees 17 (4), 351 358

Chang, X.X., Zhao, W.Z., Zhang, Z.H., Su, Y.Z., 2006. Sap flow and tree conductance of shelter-belt in arid region of China. Agric. Forest Meteorol. 138 (1-4), 132-141.

Cheng, D.H., Li, Y., Chen, X.H., Wang, W.K., Hou, G.C., Wang, C.L., 2013. Estimation of groundwater evaportanspiration using diurnal water table fluctuations in the Mu Us Desert, northern China. J. Hydrol. 490, 106-113.

Cooper, D.J., D’Amico, D.R., Scott, M.L., 2003. Physiological and morphological response patterns of Populus deltoides to alluvial groundwater pumping. Environ. Manage. 31 (2), 215-226.

Cooper, D.J., Sanderson, J.S., Stannard, D.I., Groeneveld, D.P., 2006. Effects of longterm water table drawdown on evapotranspiration and vegetation in an arid region phreatophyte community. J. Hydrol. 325 (1-4), 21-34.

Domec, J.C., Gartner, B.L., 2002. How do water transport and water storage differ in coniferous earlywood and latewood? J. Exp. Bot. 53 (379), 2369-2379.

Eberbach, P.L., Burrows, G.E., 2006. The transpiration response by four topographically distributed Eucalyptus species, to rainfall occurring during drought in south eastern Australia. Physiol. Plant. 127 (3), 483-493.

Engel, V., Jobbagy, E.G., Stieglitz, M., Williams, M., Jackson, R.B., 2005. Hydrological consequences of eucalyptus afforestation in the argentine pampas. Water Resour. Res. 41 (10), W10409. http://dx.doi.org/10.1029/2004wr003761.

Ewers, B.E., Oren, R., 2000. Analyses of assumptions and errors in the calculation of stomatal conductance from sap flux measurements. Tree Physiol. 20 (9), 579589.

Gazal, R.M. Scott, R.L., Goodrich, D.C. Williams, D.G, 2006. Controls on transpiration in a semiarid riparian cottonwood forest. Agric. Forest Meteorol. 137, 56-67.

Gou, S., Miller, G., 2014. A groundwater-soil-plant-atmosphere continuum approach for modelling water stress, uptake, and hydraulic redistribution in phreatophytic vegetation. Ecohydrology 7, 1029-1041.

Gribovszki, Z., Szilagyi, J., Kalicz, P., 2010. Diurnal fluctuations in shallow groundwater levels and streamflow rates and their interpretation-a review. J. Hydrol. 385, 371-383.

Granier, A., 1985. A new method of sap flow measurement in tree stems. Ann. Sci. For. 42 (2), 193-200.

Granier, A., 1987. Evaluation of transpiration in a Douglas-fir stand by means of sap flow measurements. Tree Physiol. 3 (4), 309-320.

Healy, R., Cook, P., 2002. Using groundwater levels to estimate recharge. Hydrogeol. J. 10 (1), 91-109.

Limousin, J.M., Rambal, S., Ourcival, J.M., Rocheteau, A., Joffre, R., Rodriguez-Cortina, R., 2009. Long-term transpiration change with rainfall decline in a Mediterranean Quercus ilex forest. Global Change Biol. 15 (9), 2163-2175.

Loheide, S.P., Butler, J.J., Gorelick, S.M., 2005. Estimation of groundwater consumption by phreatophytes using diurnal water table fluctuations: a saturated-unsaturated flow assessment. Water Resour. Res. 41, W07030. http://dx.doi.org/10.1029/2005wr003942.

Ma, J.X., Huang, X., Li, W.H., Zhu, C.G., 2013. Sap flow and trunk maximum daily shrinkage (MDS) measurements for diagnosing water status of Populus euphratica in an inland river basin of Northwest China. Ecohydrology 6, 9941000.

Martinet, M.C., Vivoni, E.R., Cleverly, J.R., Thibault, J.R., Schuetz, J.F., Dahm, C.N., 2009. On groundwater fluctuations, evapotranspiration, and understory 
removal in riparian corridors. Water Resour. Res. 45, W05425. http://dx.doi.org/ 10.1029/2008wr007152.

Mazur, M.L.C., Wiley, M.J., Wilcox, D.A., 2014. Estimating evapotranspiration and groundwater flow from water-table fluctuations for a general wetland scenario. Ecohydrology 7, 378-390.

Miller, G.R., Chen, X., Rubin, Y., Ma, S., Baldocchi, D.D., 2010. Groundwater uptake by woody vegetation in a semiarid oak savanna. Water Resour. Res. 46, W10503. http://dx.doi.org/10.1029/2009wr008902.

Motzer, T., Munz, N., Küppers, M., Schmitt, D., Anhuf, D., 2005. Stomatal conductance, transpiration and sap flow of tropical montane rain forest trees in the southern Ecuadorian Andes. Tree Physiol. 25 (10), 1283-1293.

Naithani, K.J., Ewers, B.E., Pendall, E., 2012. Sap flux-scaled transpiration and stomatal conductance response to soil and atmospheric drought in a semi-arid sagebrush ecosystem. J. Hydrol. 464-465, 176-185.

O'Grady, A.P., Worledge, D., Battaglia, M., 2008. Constraints on transpiration of Eucalyptus globulus in southern Tasmania, Australia. Agric. For. Meteorol. 148 (3), 453-465.

Oren, R., Sperry, J.S., Ewers, B.E., Pataki, D.E., Phillips, N., Megonigal, J.P., 2001. Sensitivity of mean canopy stomatal conductance to vapor pressure deficit in a flooded Taxodium distichum L. forest: hydraulic and non-hydraulic effects. Oecologia 126 (1), 21-29.

Oren, R., Sperry, J.S., Katul, G.G., Pataki, D.E., Ewers, B.E., Phillips, N., Schafer, K.V.R. 1999. Survey and synthesis of intra-and interspecific variation in stomatal sensitivity to vapour pressure deficit. Plant Cell Environ. 22 (12), 1515-1526.

Oren, R., Zimmermann, R., Terborgh, J., 1996. Transpiration in upper Amazonia floodplain and upland forests in response to drought-breaking rains. Ecology 77 (3), 968-973.

Phillips, N., Oren, R., 1998. A comparison of daily representations of canopy conductance based on two conditional time-averaging methods and the dependence of daily conductance on environmental factors. Ann. Sci. For. 55 (1-2), 217-235.

Pinto, C.A., Nadezhdina, N., David, J.S., Kurz-Besson, C., Caldeira, M.C., Henriques, M. O., Monteiro, F.G., Pereira, J.S., David, T.S., 2014. Transpiration in Quercus suber trees under shallow water table conditions: the role of soil and groundwater. Hydrol. Process. 28, 6067-6079.

Poyatos, R., Llorens, P., Gallart, F., 2005. Transpiration of montane Pinus sylvestris L. and Quercus pubescens Willd. forest stands measured with sap flow sensors in NE Spain. Hydrol. Earth Syst. Sci. 9 (5), 493-505.

Prieto, I., Kikvidze, Z., Pugnaire, F.I., 2010. Hydraulic lift: soil processes and transpiration in the Mediterranean leguminous shrub Retama sphaerocarpa (L.) Boiss. Plant Soil. 329 (1-2), 447-456.
Roccuzzo, G., Villalobos, F.J., Testi, L., Fereres, E., 2014. Effects of water deficits on whole tree water use efficiency of orange. Agric. Water Manage. 140, 61-68.

Schilling, K.E., 2007. Water table fluctuations under three riparian land covers, Iowa (USA). Hydrol. Process. 21, 2415-2424.

Schwärzel, K. Menzer, A. Clausnitzer, F. Spank, U. Hantzschel, J. Grunwald, T., Kostner, B., Bernhofer, C., Feger, K.H., 2009. Soil water content measurements deliver reliable estimates of water fluxes: a comparative study in a beech and a spruce stand in the Tharandt forest (Saxony, Germany). Agric. Forest Meteorol. 149 (11), 1994-2006.

Shen, Q., Gao, G., Fu, B., Lü, Y., 2014. Sap flow and water use sources of shelter-belt trees in an arid inland river basin of Northwest China. Ecohydrology. http://dx. doi.org/10.1002/eco.1593.

Vincke, C., Thiry, Y., 2008. Water table is a relevant source for water uptake by a scots pine (Pinus sylvestris L.) stand: evidences from continuous evapotranspiration and water table monitoring. Agric. For. Meteorol. 148 (10), 1419-1432.

Vourlitis, G.L., Priante, N., Hayashi, M.M.S., Nogueira, J.D., Caseiro, F.T., Campelo, J.H. 2002. Seasonal variations in the evapotranspiration of a transitional tropical forest of Mato Grosso, Brazil. Water Resour. Res. 38 (6). http://dx.doi.org/ 10.1029/2000wr000122.

Wang, G., Cheng, G., 2000. The characteristics of water resources and the changes of the hydrological process and environment in the arid zone of northwest China. Environ. Earth Sci. 39 (7), 783-790.

Wang, P., Grinevsky, S.O., Pozdniakov, S.P., Yu, J.J., Dautova, D.S., Min, L.L., Du, C.Y., Zhang, Y.C., 2014. Application of the water table fluctuation method for estimating evapotranspiration at two phreatophyte-dominated sites under hyper-arid environments. J. Hydrol. 519, 2289-2300.

White, W. (Ed.), 1932. A method for estimating ground-water supplies based on discharge by plants and evaporation from soil. US Geol. Survey Water Supply Paper 659-A. United States Government Printing Office, Washington, DC.

Wilkinson, S., Davies, W.J., 2002. ABA-based chemical signalling: the co-ordination of responses to stress in plants. Plant Cell Environ. 25 (2), 195-210.

Williams, D.G., Cable, W., Hultine, K., Hoedjes, J.C.B., Yepez, E.A., Simonneaux, V., ErRaki, S., Boulet, G., de Bruin, H.A.R., Chehbouni, A., Hartogensis, O.K., Timouk, F., 2004. Evapotranspiration components determined by stable isotope, sap flow and eddy covariance techniques. Agric. For. Meteorol. 125 (3-4), 241-258.

Zhao, W.Z., Liu, B., 2010. The response of sap flow in shrubs to rainfall pulses in the desert region of China. Agric. For. Meteorol. 150 (9), 1297-1306. 